\title{
Didactic Modelling for Socio-Ecojustice
}

\author{
JESPER SJÖSTRÖM*
}

${ }^{*}$ Faculty of Education and Society, Department of Science-Mathematics-Society, Malmö University, SE-205 06

Malmö, Sweden; jesper.sjostrom@mau.se

\section{Responses}

JASTE is a non-refereed, open-access, journal. We encourage reader feedback on contributions to it. Please send your comments, suggestions, etc. directly to the author of this paper, Associate Professor Jesper Sjöström. Thanks!

\begin{abstract}
In northern Europe and Scandinavia, there is a tradition called Didaktik. It can be seen as both the art of teaching and as the "science for teachers", helping us teachers answering didactic questions about WHY?, WHAT? and HOW? to teach (and support learning). Many areas of subject-specific Didaktik have in recent decades evolved from mainly practice-based methodology to quite independent research areas. This applies, for example, to the field of science-Didaktik (i.e., Science Education). Part of this field has a special interest in educational activities for socio-ecojustice. For instance, it can include complex issues used in teaching to build bridges across different curriculum subjects, among them STEM-subjects, in support of sustainability, reflexive Bildung and socio-political activism. The focus in this paper is on socalled didactic models and modelling aiming at actions for socio-ecojustice. In particular, the paper presents a model for eco-reflexive Didaktik, an example of a didactic model. Didactic modelling is the name for the processes when didactic models are used and developed, often by researchers in collaboration with practitioners. The didactic model in focus here is based on philosophical ideas and orientations, such as holism, critical realism, egalitarianism, altruism, reconstructionism and critical pedagogy.
\end{abstract}

Keywords: education for sustainability, eco-reflexive education, critical scientific literacy, Vision III, powerful knowledge, Bildung, socio-political activism, Didaktik, didactic models, didactic modelling

\section{Didaktik as the teachers' science and its relationship to Bildung}

In northern Europe and Scandinavia, there is a tradition called Didaktik. It can be seen as both the art of teaching and as the "science for teachers" (e.g. Seel, 1999; Hopmann, 2007; Kansanen, 2009). Though there are a variety of definitions, the most comprehensive is that it is "a science and theory about teaching and learning in all circumstances and in all forms" (Gundem, 2010, p. 293). According to Duit (2015, p. 325) Didaktik "stands for a multifaceted view of planning and performing instruction. It is based on the German concept of Bildung". The latter is the German and international term for an educationalphilosophical key idea in German-speaking countries and Scandinavia (e.g. Sjöström, Frerichs, Zuin \& Eilks, 2017). It is especially in the humanistic Didaktik-tradition that the notion of Bildung is central (see e.g. Fischler, 2011; Jank, 2014; Vásquez-Levy, 2002). See Westbury, Hopmann and Riquarts (2000) for some translated original contributions from the history of Didaktik and Bildung. Both the concepts will be described further below.

The German Bildung-scholar Wolfgang Klafki framed his Bildung concept with epoch-typical key issues, such as the global challenges (e.g. Arnold, 2012; Sjöström \& Eilks, 2018). He identified two main orientations in his understanding of Bildung: material and formal Bildung, respectively. Furthermore, he also argued for a position mixing these two views and called it categorical Bildung (Sjöström \& Eilks, accepted). More recently, Kemp (2005, in English 2010) applied the thinking of Klafki to ideas about our late modern society. Moreover, he discussed different views of the "world citizen". Kemp described education - just like Klafki did - as being embedded in a certain time, society and culture. 
In recent decades, many areas of subject-specific Didaktik have evolved from mainly practice-based methodology to quite independent research areas (Sjöström, 2018a). This applies, for instance, to the field of science-Didaktik (i.e., Science Education). Part of this field has a special interest in educational activities for socio-ecojustice. For example it can include complex controversial issues used in teaching to build bridges across different curriculum subjects - among them STEM-subjects - in support of sustainability, reflexive Bildung and socio-political activism (Sjöström \& Rydberg, 2018).

In teaching practice, so-called Didaktik-models (in the following called didactic models) can be used both as tools for analysis and for planning of teaching (e.g. Arnold, 2012; Jank \& Meyer, 2018). The main aim of didactic models is to help us teachers in our didactic choices (e.g. Wickman, Hamza \& Lundegård, 2018; Sjöström, 2019). Models can be used, for example, in the design, action and analysis of teaching, but also for critical meta-reflection about teaching traditions, prevalent practices or didactical dilemmas. There are three main types of didactic models, although many models - as the one in focus in this paper - are mixtures of these:

- Relevance models, which help us answer the didactic WHY-question (it is about intentions, aims and objectives)

- Content models, which help us answer the didactic WHAT-question (it is about topics of instruction)

- Models for improved practice, which help us answer the didactic HOW-question (it is about methods of instruction and media used in instruction)

The Didaktik tradition focuses predominantly on the WHY- and WHAT-questions, while the AngloAmerican teaching tradition focuses more directly on the HOW-question (e.g. Kansanen, 1999; Duit, 2015). Klafki developed didactic models for Bildung-oriented Didaktik (e.g. Vásquez-Levy, 2002). For the science subjects Professor Ingo Eilks from the University of Bremen, Germany, together with coworkers has formulated and empirically evaluated a didactic model for socio-critical and Bildung-oriented science teaching (e.g. Marks, Stuckey, Belova \& Eilks, 2014). I, with Eilks in particular, have further elaborated on the Bildung-concept in relation to the science subjects (e.g. Sjöström, 2013; Sjöström et al., 2017; Sjöström \& Talanquer, 2018).

When didactic models are formulated, used and/or developed, this may be referred to as 'didactic modelling' (Sjöström, 2019). In this paper, the focus is on didactic models and modelling aiming at actions and activism for socio-ecojustice. By activism in science and technology education I mean the same as Alsop and Bencze (2014) did. In particular, the paper presents a model for eco-reflexive Didaktik, an example of a didactic model.

The rest of the paper is subdivided into the following four parts: Didactic models and modelling; Powerful knowledge, critical literacy and eco-reflexive Bildung; Science education for socio-political activism; and A didactic model for socio-ecojustice.

\section{Didactic models and modelling}

Two fundamental didactic models are the didactic questions (WHY?, WHAT?, HOW? etc.) and the classical didactic triangle (teacher-content-student) (see Figure 1). However, there are many more models: both comprehensive and detailed, abstract and concrete, and general and subject-specific (Sjöström, 2019). Didactic models can be used both as analysis tools and as tools in the planning of teaching (e.g. Arnold, 2012; Wickman, 2014; Jank \& Meyer, 2018). Almqvist, Hamza and Olin (2017, p. 21) write (my translation): "Didactic models can look different and have different purposes. In particular, they should enable didactic analysis of any part of the teaching, such as the selection of teaching content, planning of how the content should be realized in the classroom, how the teaching should be assessed or to understand what happened during the lesson, why it happened and how the teaching could be modified". There are also more comprehensive didactic models on, for instance, philosophical views, teaching traditions and teacher competencies. 
WHY? Philosophical Ideas WHAT? Choices of Context and Content

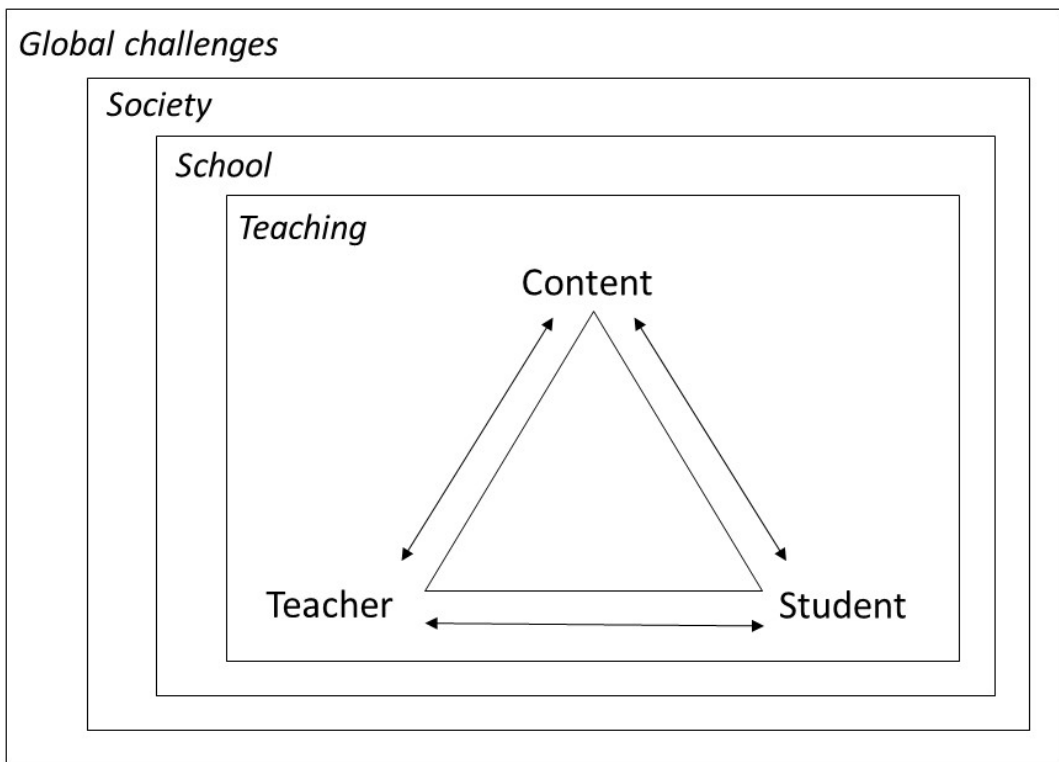

HOW? Pedagogy and Methods

\section{Figure 1. Two fundamental didactic models, the didactic questions and the classical didactic triangle in an expanded form.}

Examples of research-based and teaching-oriented didactic models are organizing purposes (Hamza et al., 2018), didactical dilemmas regarding controversial issues teaching (Rydberg, 2018; Sjöström \& Rydberg, 2018) and key elements in teaching about risk (Schenk et al., 2019). The models have the potential to change practice, but practice will also affect the models. Such interaction between theory and practice has been called didactic modelling (e.g. Ingerman \& Wickman, 2015). Blomhøj and Højgaard Jensen (2007, p. 26) have another take on didactic modelling (my translation): "Didactic modelling is our term for a systematic, research-based and reflected development of an education practice". In other words, it means that didactic knowledge is developed by teachers in collaboration, in one way or another, with Didaktikresearchers (e.g. Ingerman \& Wickman, 2015; Hamza et al., 2018); moreover, it creates opportunities for teachers' systematic development of their teaching. The starting point is always one or more didactic models that are tested and refined in teaching practice (Sjöström, 2019).

Didactic models can be traced back to Klafki's didactic analyses in the late 1950s, with five areas of questions (Klafki, 1995; Duit, 2015; Sjöström \& Eilks, accepted). Ingerman and Wickman (2015) see didactic models as a way of introducing us as teachers to a more general form of didactic analysis. We must balance different purposes of teaching with each other, thus focusing on the different functions that education should meet, that is, qualification, socialization and subjectification (Biesta, 2009). In this paper, the focus is on what can be called emancipatory subjectification. Students should not be forced to have any specific views or values - except general democratic thinking - but education always needs to expose students to and highlight well-informed alternative views, thinking and facts to give them the possibility to question mainstream and/or antidemocratic discourses. In line with these thoughts, Alexander (2018, p. 914) phrased the following: "Pedagogy worthy of the designation 'critical' must not only initiate into particular ethical viewpoints but also offer exposure to alternative perspectives". Similarly, but with more focus on content matter and within the European didactic tradition, Hopmann (2007, p. 117) claims, "Didaktik and Bildung require normativeness [...] they challenge the teacher to be aware of the unavoidable normativeness in every dealing with whatever subject matter." 


\section{Powerful knowledge, critical literacy and eco-reflexive Bildung}

One understanding of our world is that we live in a risk society (Beck, 1992), in which citizens, professionals and politicians must be aware of and able to manage different risks. Scientific knowledge is one of several necessary knowledge bases (Elmose \& Roth, 2005). In line with this, science and technology education must be designed with the purpose of educating critical-democratic citizens (e.g. Sjöström \& Eilks, 2018). Hodson (2011) has argued for a critical scientific, technological and environmental literacy shortened to critical scientific literacy. The aim of critical scientific literacy is to have knowledge and abilities for being an autonomous, responsible-taking and action-knowledgeable citizen, working in the interest of socio-ecojustice and global sustainability. Elmose and Roth (2005, p. 21) called this Bildung, and it "involves competences for self-determination, constructive participation in society, and solidarity towards persons limited in the competence of self-determination and participation". It is praxis-oriented, in addition to being oriented towards consciousness and critical literacy. In line with this, Mogensen and Schnack (2010, p. 60) argued that their concept of action competence is "closely linked to democratic, political education and to $[\ldots]$ the notion of 'Bildung.".

According to Biesta (2012a, p. 817), "the role of the individual in the process of Bildung, [...] has to be understood as a reflexive process", that is, a process were the individual establishes both a relationship and a critical stance towards the existing culture and society. In this process of emancipatory subjectification, the individuals become "autonomous - subjects of action and responsibility" (Biesta, 2012b, p. 7). This phrase "tries to capture a conception of human subjectivity that is not selfish or self-centered but always understood as being in responsible relation with other human beings and, by extension, with the natural world more generally" (Biesta, 2013, p. 739). Biesta (2012b, p. 16) regards this as "highly political, as it intervenes in and reconfigures the existing order of things". To specify the meaning of Bildung today, we have to base it on the fact that we live in a globalised risk society with many global and ecological challenges (e.g. Straume, 2015; Taylor, 2017; Sjöström et al., 2017; Roselius \& Meyer, 2018). Horlacher (2016, p. 118) has asserted that Bildung can be "seen as a tool to promote political education, and foster public spirit and identity" in our society. When it is oriented towards ecological awareness, I have previously called such an orientation eco-reflexive Bildung (Sjöström, 2018b).

Outside the Bildung-traditions, but with many similarities to Klafki's categorical Bildung-thinking (Bladh, Stolare \& Kristiansson, 2018), Young (2013) emphasised the need of every citizen to have socalled powerful knowledge. It is relevant knowledge developed within disciplinary contexts. In other words, it refers to discipline-grounded knowledge important for all. Young (2013, p. 118) contends that "Powerful knowledge opens doors: it must be available to all children [...] It transcends and liberates children from their daily experience."

In traditional science education, the focus has been on scientific concepts and models. Compared to both the "powerful knowledge"-conceptualisation by Young and the "categorical Bildung"-thinking by Klafki, a relevance focus has been missing. In addition to (a) scientific concepts and models, both (b) scientific processes - NOS (Nature of Science) - and (c) societal contexts - STSE (Science-TechnologySociety-Environment) - should be emphasised in a socio-critical and eco-reflexive Bildung-oriented science education (Sjöström \& Eilks, 2018). In practice, it would mean including more philosophical, ethical and socio-political perspectives in science teaching, and the focus should be on problematization, understanding uncertainties and balancing the benefits and risks of science. In addition to these three legs - concepts, NOS and STSE - Hodson (2003) also suggested socio-political activism as a fourth leg. In a paper about different ways of using the concept of Bildung in the international science education literature, I together with co-authors merged NOS- and STSE-contextualisations to one approach and called the remaining three approaches conceptual, contextual and critical (Sjöström et al., 2017, p. 182). The latter approach is connected to eco-reflexive Bildung and also a Vision III of scientific literacy. The meaning of Vision III will be presented in the next section. 


\section{Science education for socio-political activism}

The dominant model for working with controversial issues in science education is referred to as socioscientific issues (SSI) (see e.g. Pedretti \& Nazir, 2011). It is typically complex and relevant social issues with a science base (see e.g. Ratcliffe \& Grace, 2003; Zeidler, Sadler, Simmons, \& Howes, 2005). However, it is not a uniform teaching model. Although the teaching has the same origin, there are several different orientations on such teaching (Pedretti \& Nazir, 2011). Simonneaux (2014) has discussed different orientations of SSI-education using a continuum from "cold" (mainly emphasizing, for instance, monodisciplinarity, scientific learning and epistemic values) to "hot" (also emphasizing transdisciplinarity, political citizenship and philosophical values). In the middle of Simonneaux's (2014) model, we find, for example, knowledge about science, critical thinking, and scientific citizenship. Although STSEcontextualization is emphasized, the focus is on cognition and evidence-based argumentation. This is problematized at the hot end, which also contains philosophical reflection and socio-political activism.

Simonneaux's (2014) chapter is published in an anthology oriented towards critical, radical and activist-oriented Science and Technology education, that is, ST education at the hot end. The editors of the anthology are Bencze and Alsop (2014). They discussed four maxims for such education praxis: contemporary conditions, democratic political theory, subjectivities and agency, and morals and ethics. Some keywords describing the anthology are sustainability discourses, Science and Technology Studies (STS), citizen science education, critical pedagogy, transformative learning, SSI, reflexive inquiry and research-informed activism-projects (Bencze \& Alsop, 2014).

Levinson (2017) has compared mainstream SSI (e.g. Zeidler et al., 2005) - placed in the middle of Simonneaux's continuum - with other science-society education approaches, such as STEM (ScienceTechnology-Engineering-Mathematics), SAQ (Socially Acute Questions), and STEPWISE (Science \& Technology Education Promoting Wellbeing for Individuals, Society \& Environments). He described the education purpose of mainstream STEM, which is at the cold end of Simonneaux's continuum, to be providing human capital. The education purpose of SSI is the development of scientific knowledge needed for socio-scientific reasoning, that of SAQ is to develop a critical discourse, and that of STEPWISE is to develop knowledge for activism and socio-ecojustice. Both SAQ and STEPWISE are at the hot end of Simonneaux's continuum. In a similar organizer, I together with Eilks used the concepts of Vision I, II and III of scientific literacy and STEM education (Sjöström \& Eilks, 2018). Vision I is at the cold end, and Vision III at the hot end (see further below).

Vision I and II relate to Roberts' (2007) two classic visions, while we introduced a third that we called Vision III (Sjöström \& Eilks, 2018). It includes critical aspects that aim at philosophical reflection and socio-political actions. Science education based on eco-reflexive Bildung and Vision III aims for both students and teachers to have a holistic, ethical and political attitude regarding STSE relationships (e.g. Sjöström, Eilks \& Zuin, 2016). One consequence of this is that teaching in curriculum subjects must orient itself towards both transdisciplinary perspectives (Sjöström \& Rydberg, 2018) and powerful knowledge (Young \& Lambert, 2014).

As a basis for SSI discussions, the students should have access to both relevant scientific research bases and socio-political contextualisation. Nielsen (2012) has argued that students' arguments will not only come from rational scientific reasoning, but they will always also be strongly influenced by the individual's ideological and ethical views and own experiences, and should be allowed to be. In hot SSI teaching, we as teachers may need to handle strong emotions, a changing teacher role and complex assessment activities. As a result, we need to be aware of both the advantages and disadvantages of the various didactical options available (Rydberg, 2018).

\section{A didactic model for socio-ecojustice}

Examples of didactic models that take the global challenges into consideration are as follows: the STEPWISE theoretical framework and pedagogical approach for activist Science and Technology education by Larry Bencze (2017, e.g. p. 20 and 27) and his co-workers, the so-called SSIBL-model 
(SSI+IBSE) developed by Ralph Levinson and the PARRISE consortium (2017, p. 480), and the model/framework for socio-critical and Bildung-oriented science teaching by Eilks and his co-workers (Marks et al., 2014). Here, I will present a developed version of the latter model/framework.

The didactic model in Figure 2 - a model for eco-reflexive Didaktik - is a revised and extended version of a "Framework outlining the socio-critical and problem-oriented approach to science teaching", initially published by Marks and Eilks (2009). It has been republished several times, for example in Marks et al. (2014) and Sjöström, Rauch and Eilks (2015). Furthermore, it has been tested (didactic modelling), in particular with chemistry teachers using different thematic themes, such as different plastics (Burmeister \& Eilks, 2012; 2014), different fuels (Eilks, 2002), parabens as preservatives in personal care products (Garner, Siol \& Eilks, 2014), soaps with artificial musk fragrances (Marks \& Eilks, 2010), tattoos (Stuckey \& Eilks, 2014), doping (Stolz, Witteck, Marks \& Eilks, 2013), and "natural" cosmetics (Belova \& Eilks, 2015). For many of these cases, one can talk about a chemical oppression, where people are exposed to different risk-related chemicals often without being aware of the fact (Belova et al., 2017). Then it is not enough with NOS- and STSE-contextualisations, in addition to scientific content knowledge. There is also a need for understanding the network of actors and the presence of various discourses (Sjöström \& Stenborg, 2014), as well as an awareness of alternatives and possibilities for action. The didactic model in Figure 2, which has not been published before, takes this need into consideration. Furthermore, it - even more explicitly than its precursor - connects to the humanistic Didaktik-tradition and the didactic questions (WHY?, WHAT?, HOW?).

\begin{tabular}{|c|c|c|c|c|}
\hline Philosophical ideas & $\begin{array}{l}\text { Objectives } \\
\text { (WHY?) }\end{array}$ & $\begin{array}{l}\text { Criteria for selecting } \\
\text { issues and approaches } \\
\text { (WHAT?) }\end{array}$ & $\begin{array}{l}\text { Teaching methods } \\
\text { (HOW?) }\end{array}$ & $\begin{array}{l}\text { Structure of lessons } \\
\text { and projects }\end{array}$ \\
\hline $\begin{array}{l}\text { Holism } \\
\text { and } \\
\text { Eco-reflexivity }\end{array}$ & $\begin{array}{c}\text { Reflexive Bildung } \\
\text { and } \\
\text { Transformative learning }\end{array}$ & Sustainability issues & $\begin{array}{l}\text { Integrating cognitive and } \\
\text { affective domains } \\
\text { (incl. dialogic processes) }\end{array}$ & 1. Problem analysis \\
\hline Critical realism & $\begin{array}{l}\text { Problematization, } \\
\text { Emancipation, } \\
\text { Subjectification, Praxis }\end{array}$ & $\begin{array}{l}\text { Relevant, controversial } \\
\text { and complex socio- } \\
\text { scientific issues }\end{array}$ & $\begin{array}{l}\text { Inquiry-based learning } \\
\text { (incl. practical work) }\end{array}$ & $\begin{array}{l}\text { 2. Clarifying the } \\
\text { science } \\
\text { background and } \\
\text { context }\end{array}$ \\
\hline $\begin{array}{l}\text { Egalitarianism } \\
\text { and Altruism }\end{array}$ & $\begin{array}{c}\text { Vision III of } \\
\text { scientific literacy }\end{array}$ & Authenticity & $\begin{array}{l}\text { Relevant media } \\
\text { (incl. authentic) }\end{array}$ & $\begin{array}{l}\text { 3. Resuming the } \\
\text { socio-political- } \\
\text { scientific } \\
\text { controversy }\end{array}$ \\
\hline $\begin{array}{l}\text { Humanization (plural } \\
\text { knowledge and } \\
\text { mutifacetted } \\
\text { problematization) }\end{array}$ & $\begin{array}{l}\text { Learning in and about } \\
\text { science } \\
\text { (incl. NOS and STSE) }\end{array}$ & $\begin{array}{l}\text { Includes scientific } \\
\text { knowledge and processes } \\
\text { (incl. uncertainty) }\end{array}$ & $\begin{array}{l}\text { Methods structuring } \\
\text { scientific reasoning and } \\
\text { controversial debating }\end{array}$ & $\begin{array}{l}\text { 4. Alternatives and } \\
\text { examples of } \\
\text { actions for socio- } \\
\text { ecojustice }\end{array}$ \\
\hline $\begin{array}{l}\text { Reconstructionism and } \\
\text { Critical pedagogy }\end{array}$ & $\begin{array}{l}\text { Promotion of critical and } \\
\text { responsible citizenship }\end{array}$ & $\begin{array}{c}\text { Allows for open } \\
\text { discussion } \\
\text { (incl. different discourses) }\end{array}$ & $\begin{array}{l}\text { Methods provoking the } \\
\text { explication of individual } \\
\text { opinions and actions }\end{array}$ & $\begin{array}{l}\text { 5. Meta-reflection } \\
\text { (incl. analysis of } \\
\text { knowledge } \\
\text { emphases and } \\
\text { possible activism) }\end{array}$ \\
\hline
\end{tabular}

Figure 2. A didactic model for eco-reflexive Didaktik. It is a developed version of a framework by Marks \& Eilks (2009) outlining a socio-critical and problem-oriented approach to science teaching.

Column one concerns the philosophical ideas behind the developed model. The initial model does not have a corresponding column. Many of the ideas in the column (holism, realism, egalitarianism, altruism) are taken from Bencze and Carter (2011). For references about (eco)reflexivity see e.g. Sjöström et al. (2016) and Boström, Lidskog and Uggla (2017). For references in science education about complex socio-environmental issues, see e.g. Colucci-Gray, Camino, Barbiero and Gray (2006); for critical realism, see e.g. Levinson (2018) and Zembylas (2006); for critical pedagogy, see e.g. Santos (2009); for reconstructionism, see e.g. Sjöström (2018b); and for humanized science/chemistry education, see e.g. Sjöström and Talanquer (2014). See also Sjöström et al. (2016); Sjöström (2018b); and Sjöström and Eilks 
(2018) for further descriptions of the theoretical frameworks used in the development of the model.

Column two relates to the objectives (the didactic WHY-question). Ideas are taken from e.g. Sjöström and Eilks (2018). Column three deals with the content (the didactic WHAT-question). Ideas are taken from e.g. Sjöström and Talanquer (2014) and Sjöström et al. (2016). Column four concerns the practice (the didactic HOW-question). Ideas are taken from e.g. Bencze (2017), and Eilks and his co-workers (e.g. Marks et al., 2014; Belova, Chang Rundgren \& Eilks, 2015). For a discussion about approaches to integrate cognitive and affective domains, see e.g. Littledyke (2008).

Column five deals with the concrete structuring of lessons and projects, and it is similar to the corresponding column in the original framework by Marks and Eilks (2009). The column concerns (1) first making a problem analysis, and (2) then clarifying the science background and context. One way to get an overview of the context from a critical perspective is to construct - or at least to study an already existing - actor-network map (Benzce, 2017). An example of an existing network map, recently published in this journal, is about the actors in the chocolate industry (Nagi, 2018). The teaching is then followed by (3) resuming the socio-political-scientific controversy, (4) identifying alternatives and examples of actions for socio-ecojustice, and (5) meta-reflection, including analysis of knowledge emphases and possible activism.

Benzce (2017, p. 34) provides the following examples of actions for socio-ecojustice: join a cooperative that avoids food from factory farms, write a letter to a member of the government, produce posters with pros and cons, advertise about anti-consumerism, organize a boycott of products from companies that use child labour, bring reusable bags to grocery stores, and collect unused electronic equipment and recycle it. In teaching practice, such general examples can be discussed with the students, but also more specific cases can be highlighted. As examples, Krstovic (2017, p. 108) highlights teens that raise awareness of the impacts of bottled water and a student that developed a YouTube video about hidden actants in cosmetic products.

As described above, the precursor model of the didactic model in Figure 2 has been tested (didactic modelling) with a broad range of themes, mostly related to health and environment. However, the developed model (Figure 2) has not (yet) been worked with in practice, but models with many similarities have been tested by Bencze (2017) and his co-workers in the STEPWISE project. They conducted action research based on different STEPWISE models. Many of their findings regarding RiNA (Researchinformed \& Negotiated Actions) projects are summarized in a figure in the STEPWISE book (Bencze, 2017, p. 667). One of the findings is that by constructing actor-network maps, students are enlightened about problematic actants and become motivated to address problems.

The didactic model presented in this paper has Science Education in focus. However, it is mainly applicable also in Technology Education and Environmental Education. To be applicable in other curriculum subjects, it has to be modified (also didactic modelling) based on the characteristics of the specific curriculum subject. Good luck with your didactic modelling for socio-ecojustice!

\section{References}

Alexander, H. A. (2018). What is critical about critical pedagogy? Conflicting conceptions of criticism in the curriculum. Educational Philosophy and Theory, 50, 903-916.

Almqvist, J., Hamza, K. \& Olin, A. (Eds.) (2017). Undersöka och utveckla undervisning - professionell utveckling för lärare [Examine and develop teaching - professional development for teachers]. Lund: Studentlitteratur. (in Swedish)

Alsop, S. \& Bencze, L. (2014). Activism! Toward a more radical science and technology education. In L. Bencze \& S. Alsop (Eds.), Activist Science and Technology Education (pp. 1-19). Dordrecht: Springer.

Arnold K.-H. (2012). Didactics, didactic models and learning. In N. M. Seel (Ed.) Encyclopedia of the Sciences of Learning (pp. 986-990). Boston: Springer. 
Beck, U. (1992). Risk society: Towards a new modernity. Newsberry Park: Sage.

Belova, N., Chang Rundgren, S. N. \& Eilks, I. (2015). Advertising and science education: a multiperspective review of the literature. Studies in Science Education, 51, 169-200.

Belova, N. \& Eilks, I. (2015). Learning with and about advertising in chemistry education with a lesson plan on natural cosmetics - a case study. Chemistry Education Research and Practice, 16, 578-588.

Belova, N., Dittmar, J., Hansson, L., Hofstein, A., Nielsen, J. A., Sjöström, J., \& Eilks, I. (2017). Crosscurricular goals and raising the relevance of science education. In K. Hahl, K. Juuti, J. Lampiselkä, J. Lavonen \& A. Uitto (Eds.), Cognitive and Affective Aspects in Science Education Research - Selected Papers from the ESERA 2015 Conference (pp. 297-307), Dordrecht: Springer.

Bencze, L. (Ed.) (2017). Science and Technology Education Promoting Wellbeing for Individuals, Societies and Environments - STEPWISE. Dordrecht: Springer.

Bencze, L. \& Alsop, S. (Eds.) (2014). Activist Science and Technology Education. Dordrecht: Springer.

Bencze, L. \& Carter, L. (2011). Globalizing students acting for the common good. Journal of Research in Science Teaching, 48, 648-669.

Biesta, G. (2009). Good Education in an age of measurement: On the need to reconnect with the question of purpose in education. Educational Assessment, Evaluation and Accountability, 21, 33-46.

Biesta, G. (2012a). Becoming world-wise: an educational perspective on rhetorical curriculum. Journal of Curriculum Studies, 44, 815-826.

Biesta, G. (2012b). Have lifelong learning and emancipation still something to say to each other? Studies in the Education of Adults, 44, 5-20.

Biesta, G. (2013). Responsive or responsible? Democratic education for the global networked society. Policy Futures in Education, 11, 733-744.

Bladh, G., Stolare, M. \& Kristiansson, M. (2018). Curriculum principles, didactic practice and social issues: Thinking through teachers' knowledge practices in collaborative work. London Review of Education, 16, 398-413.

Blomhøj, M. \& Højgaard Jensen, T (2007). SOS-projektet - didaktisk modellering af et sammanhæengsproblem [The SOS project - didactic modelling of a contextual problem]. MONA Matematik- og Naturfagsdidaktik, nr. 3, s. 25-53. (in Danish)

Boström, M., Lidskog, R. \& Uggla, Y. (2017). A reflexive look at reflexivity in environmental sociology. Environmental Sociology, 3, 6-16.

Burmeister, M. \& Eilks, I. (2012). An example of learning about plastics and their evaluation as a contribution to Education for Sustainable Development in secondary school chemistry teaching. Chemistry Education Research and Practice, 13, 93-102.

Burmeister, M. \& Eilks, I. (2014). A lesson plan to develop structured discussion of the benefits and disadvantages of selected plastics using the product-testing method. School Science Review, 95(353), 47-54.

Colucci-Gray, L., Camino, E., Barbiero, G. \& Gray, D. (2006). From scientific literacy to sustainability literacy: An ecological framework for education. Science Education, 90, 227-252.

Duit, R. (2015). Didaktik. In R. Gunstone (Ed.), Encyclopedia of Science Education (pp. 325-327). Dordrecht: Springer.

Eilks, I. (2002). Teaching 'biodiesel': a sociocritical and problemoriented approach to chemistry teaching and students' first views on it. Chemistry Education Research and Practice, 3, 77-85.

Elmose, S. \& Roth, W.-M. (2005). Allgemeinbildung: readiness for living in risk society. Journal of Curriculum Studies, 37, 11-34. 
Fischler, H. (2011). Didaktik - an appropriate framework for the professional work of science teachers? In D. Corrigan, J. Dillon \& R. Gunstone (eds.), The professional knowledge base of science teaching (pp. 31-50). Dordrecht: Springer.

Garner, N., Siol, A. \& Eilks, I. (2014). Parabens as preservatives in personal care products. Chemistry in Action, 103, 38-43.

Gundem, B. (2010). Didactics-Didaktik-Didactique. In C. Kridel (Ed.), Encyclopedia of Curriculum Studies (pp. 293-294). Thousand Oaks: SAGE.

Hamza, K., Palm, O., Palmqvist, J., Piqueras, J. \& Wickman, P. O. (2018). Hybridization of practices in teacher-researcher collaboration. European Educational Research Journal, 17, 170-186.

Hodson, D. (2003). Time for action: Science education for an alternative future. International Journal of Science Education, 25, 645-670.

Hodson, D. (2011). Looking to the future: Building a curriculum for social activism. Rotterdam: Sense.

Hopmann, S. (2007). Restrained teaching: the common core of Didaktik. European Educational Research Journal, 6, 109-124.

Horlacher, R. (2016). The educated subject and the German concept of Bildung - a comparative cultural history. London: Routledge.

Ingerman, A. \& Wickman, P.-O. (2015). Towards a teachers' professional discipline: Shared responsibility for didactic models in research and practice. In P. Burnard, B.-M. Apelgren \& N. Cabaroglu (Eds.), Transformative teacher research: theory and practice for the C21st (pp. 167-179). Rotterdam: Sense.

Jank, W. (2014). Didaktik, Bildung, Content - on the writings of Frede V. Nielsen. Philosophy of Music Education Review, 22, 113-131.

Jank, W. \& Meyer, H. (2018). Didaktische Modelle [Didactic models]. $12^{\text {th }}$ ed., Berlin: Cornelsen Verlag Scriptor. (in German)

Kansanen, P. (1999). The Deutsche Didaktik and the American research on teaching. In B. Hudson, F. Buchberger, P. Kansanen \& H. Seel (Eds.), Didaktik/Fachdidaktik as science(-s) of the teaching profession? Vol. 2 (pp. 21-35). Umeå: Thematic Network of Teacher Education in Europe Publications.

Kansanen, P. (2009). Subject-matter didactics as a central knowledge base for teachers, or should it be called pedagogical content knowledge? Pedagogy, Culture \& Society, 17, 29-39.

Kemp, P. (2005, in English 2010). Världsmedborgaren: Politisk och pedagogisk filosofi för det 21 århundradet [Citizen of the World: Cosmopolitan Ideals for the $21^{\text {st }}$ Century]. Göteborg: Daidalos. (in Swedish)

Klafki, W. (1995). Didactic analysis as the core of preparation of instruction. Journal of Curriculum Studies, $27,13-30$.

Krstovic, M. (2017). Learning about youth engagement in research-informed and negotiated actions on socio-scientific issues. In L. Bencze (Ed.), Science and Technology Education Promoting Wellbeing for Individuals, Societies and Environments - STEPWISE (pp. 93-114). Dordrecht: Springer.

Levinson, R. (2017). SAQs as a socio-political programme: Some challenges and opportunities. SisyphusJournal of Education, 5, 25-39.

Levinson, R. (2018). Realising the school science curriculum. The Curriculum Journal, 29, 522-536.

Levinson, R. \& the PARRISE consortium (2017). Socio-scientific inquiry-based learning: Taking off from STEPWISE. In L. Bencze (Ed), Science and Technology Education Promoting Wellbeing for Individuals, Societies and Environments - STEPWISE (pp. 477-502). Dordrecht: Springer.

Littledyke, M. (2008). Science education for environmental awareness: approaches to integrating cognitive and affective domains. Environmental Education Research, 14, 1-17. 
Marks, R. \& Eilks, I. (2009). Promoting scientific literacy using a socio-critical and problem-oriented approach to chemistry teaching: concept, examples, experiences. International Journal of Environmental and Science Education, 4, 131-145.

Marks, R. \& Eilks, I. (2010). Research-based development of a lesson plan on shower gels and musk fragrances following a socio-critical and problem-oriented approach to chemistry teaching. Chemistry Education Research and Practice, 11, 129-141.

Marks, R., Stuckey, M., Belova, N. \& Eilks, I. (2014). The societal dimension in German science education - From tradition towards selected cases and recent developments. Eurasia Journal of Mathematics, Science \& Technology Education, 10, 285-296.

Mogensen, F. \& Schnack, K. (2010). The action competence approach and the 'new' discourses of education for sustainable development, competence and quality criteria. Environmental Education Research, 16, 59-74.

Nagi, F. (2018). How ethical is your chocolate? Journal for Activist Science and Technology Education, 9, 38-41

Nielsen, J. A. (2012). Co-opting science: A preliminary study of how students invoke science in valueladen discussions. International Journal of Science Education, 34, 275-299.

Pedretti, E. \& Nazir, J. (2011). Currents in STSE education: Mapping a complex field, 40 years on. Science Education, 95, 601-626.

Ratcliffe, M. \& Grace, M. (2003). Science education for citizenship. Maidenhead: Open University Press.

Roberts, D. A. (2007). Scientific Literacy / Science Literacy. In S. K. Abell \& N. G. Lederman (Eds.), Handbook of Research on Science Education (pp. 729-780). Mahwah: Lawrence Erlbaum.

Roselius, K. \& Meyer, M. A. (2018). Bildung in globalizing times. Zeitschrift für Erziehungswissenschaft, 21 , 217-240.

Rydberg, C. (2018). Didaktiska dilemman i undervisning utifrån sambällsdilemman [Didactical dilemmas while teaching controversial socioscientific issues]. Licentiat thesis, Malmö: Malmö University. (in Swedish)

Santos, W. L. P. (2009). Scientific literacy: A Freirean perspective as a radical view of humanistic science education. Science Education, 93, 361-382.

Schenk, L., Hamza, K. M., Enghag, M., Lundegård, I., Arvanitis, L., Haglund, K. \& Wojcik, A. (2019). Teaching and discussing about risk: seven elements of potential significance for science education. International Journal of Science Education, 41, 1271-1286.

Seel, H. (1999). Didaktik as the professional science of teachers. In B. Hudson, F. Buchberger, P. Kansanen \& H. Seel (Eds.), Didaktik/Fachdidaktik as science(-s) of the teaching profession? Vol. 2 (pp. 85-94). Umeå: Thematic Network of Teacher Education in Europe Publications.

Simonneaux, L. (2014). From promoting the techno-sciences to activism - a variety of objectives involved in the teaching of SSIs. In L. Bencze \& S. Alsop (Eds.), Activist Science and Technology Education (pp. 99-111). Dordrecht: Springer.

Sjöström, J. (2013). Towards Bildung-oriented chemistry education. Science \& Education, 22, 1873-1890.

Sjöström, J. (2018a). Didaktik i integrativa lärarprofessionsämnen [Didactics in integrative teacher profession subjects]. Studier i lareruddannelse og -profession, 3, 94-119. (in Swedish)

Sjöström, J. (2018b). Science teacher identity and eco-transformation of science education: comparing Western modernism with Confucianism and reflexive Bildung. Cultural Studies of Science Education, 13, 147-161.

Sjöström, J. (2019). Didaktisk modellering [Didactic modelling]. In K. Stolpe, G. Höst \& A. Larsson (Eds.), Forum för forskningsbaserad NT-undervisning. Bidrag frän konferensen FobasNT18 13 - 14 mars 
2018 i Norrköping (pp. 121-132), nr. 3 i skriftserien Naturvetenskapernas och teknikens didaktik. Linköping: Linköping University Electronic Press. (in Swedish)

Sjöström, J. \& Eilks, I. (2018). Reconsidering different visions of scientific literacy and Science Education based on the concept of Bildung. In Y. Dori, Z. Mevarech, D. Baker (Eds.), Cognition, Metacognition, and Culture in STEM Education (pp. 65-88). Dordrecht: Springer.

Sjöström, J. \& Eilks, I. (accepted). The Bildung theory - from von Humboldt to Klafki and beyond. In B. Akpan \& T. Kennedy (Eds.), Science Education in Theory and Practice. Dordrecht: Springer.

Sjöström, J., Eilks, I. \& Zuin, V. G. (2016). Towards eco-reflexive science education - a critical reflection about educational implications of green chemistry. Science \& Education, 25, 321-341.

Sjöström, J., Frerichs, N., Zuin, V. G. \& Eilks, I. (2017). Use of the concept of Bildung in the international science education literature, its potential, and implications for teaching and learning. Studies in Science Education, 53, 165-192.

Sjöström, J., Rauch, F. \& Eilks, I. (2015). Chemistry education for sustainability. In I. Eilks \& A. Hofstein (Eds.) Relevant chemistry education - from theory to practice (pp. 163-184), Rotterdam: Sense.

Sjöström, J. \& Rydberg, C. (2018). Towards transdisciplinary Didaktik - didactic modelling of complex controversial issues teaching for reflexive Bildung and sustainability. In I. Eilks, S. Markic \& B. Ralle (Eds.), Building Bridges Across Disciplines for Transformative Education and a Sustainable Future (pp. 3-15), Aachen: Shaker Verlag.

Sjöström, J. \& Stenborg, E. (2014). Teaching and learning for critical scientific literacy: communicating knowledge uncertainties, actors interplay and various discourses about chemicals. In I. Eilks, S. Markic \& B. Ralle (Eds.), Science Education Research and Education for Sustainable Development (pp. 3748), Aachen: Shaker Verlag.

Sjöström, J. \& Talanquer, V. (2014). Humanizing chemistry education: from simple contextualization to multifaceted problematization. Journal of Chemical Education, 91, 1125-1131.

Sjöström, J. \& Talanquer, V. (2018). Eco-reflexive chemical thinking and action. Current Opinion in Green and Sustainable Chemistry, 13, 16-20.

Stolz, M., Witteck, T., Marks, R. \& Eilks, I. (2013). Reflecting socio-scientific issues for science education coming from the case of curriculum development on doping in chemistry education. Eurasia Journal of Mathematics, Science \& Technology Education, 9, 361-370.

Straume, I. S. (2015). The subject and the world: educational challenges. Educational Philosopby and Theory, $47,1465-1476$.

Stuckey, M. \& Eilks, I. (2014). Increasing student motivation and the perception of chemistry's relevance in the classroom by learning about tattooing from a chemical and societal view. Chemistry Education Research and Practice, 15, 156-167.

Taylor, C. A. (2017). Is a posthumanist Bildung possible? Reclaiming the promise of Bildung for contemporary higher education. Higher Education, 74, 419-435.

Vásquez-Levy, D. (2002). Bildung-centred Didaktik: a framework for examining the educational potential of subject matter. Journal of Curriculum Studies, 34, 117-128.

Westbury, I., Hopmann, S. \& Riquarts, K. (Eds.). (2000). Teaching as a reflective practice: The German Didaktik tradition. Mahwah: Lawrence Erlbaum.

Wickman, P.-O. (2014). Teaching learning progressions: An international perspective. In N. G. Lederman \& S. K. Abell (Eds.), Handbook of Research on Science Education (pp. 145-163), $2^{\text {nd }}$ ed., New York: Routledge. 
Wickman, P.-O., Hamza, K. \& Lundegård, I. (2018). Didaktik och didaktiska modeller för undervisning i naturvetenskapliga ämnen [Didactics and didactic models in science education]. NorDiNa - Nordic Studies in Science Education, 14, 239-249. (in Swedish)

Young, M. (2013). Overcoming the crisis in curriculum theory: a knowledge-based approach. Journal of Curriculum Studies, 45, 101-118.

Young, M. \& Lambert, D. (2014). Knowledge and the future school - curriculum and social justice. London: Bloomsbury.

Zeidler, D. L., Sadler, T. D., Simmons, M. L. \& Howes, E. V. (2005). Beyond STS: a research-based framework for socioscientific issues education. Science Education, 89, 357-377.

Zembylas, M. (2006). Science education as emancipatory: the case of Roy Bhaskar's philosophy of metareality. Educational Philosophy and Theory, 38, 665-676. 